DOI: 10.25108/2304-1730-1749.iolr.2020.62.6-14

UDC 34:341

\title{
Securing human rights during armed conflicts
}

Abstract: For centuries, armed conflicts have destroyed millions of lives. During the armed conflicts serious violations of laware observed. In some cases, some of these violations even occur in the form of genocide and war crimes.

International human rights law and international humanitarian law share the goal of preserving the dignity and humanity of all.

This article provides a legal analysis of international human rights law and international humanitarian law for the protection of persons in armed conflict. It, also, addresses the complementary application of these two bodies of law and examinespractical approach of European Court of Human Rights on some of the issues raised by the concurrent applicability of international humanitarian law and European human rights law.

Keywords: armed conflicts; human rights; international law; humanitarian law; states; civilian population; victims; weapons

"In time of war, the law is silent", Cicero famously declared. Yet for many years soldiers, statesmen, scholars and theologians have struggled to establish boundaries that would mitigate the horrors of warfare.

The protection of civilians from human rights violations during armed conflict became an issue of global attention and concern through the 1990s, during the post-Cold War era of violent transition and state collapse in which parties to conflict ignored international safeguards to commit atrocities against men, women, and children, while the international community failed to act to prevent these abuses [11, p.1]. The massacres in Karabakh region of the Republic of Azerbaijan, Rwanda and Srebrenica in Bosnia and Herzegovina, and widespread abuse of civilians during the wars in the African Great Lakes region, West Africa, Somalia and elsewhere were indicators of the failure of all to protect civilians.

One of the most disturbing results of warfare is the deleterious effect that might be observed on non-combatants. Harm to civilians in warfare and its aftermath takes largely two forms. The first, and most obvious, are civilians who suffer death or serious injury as a direct result of combat. The second are those who suffer other assaults on their dignity (such as sexual assault, ethnic violence, etc.) as a result of the breakdown of law and order, resulting in a security vacuum in which such violations run rife. Such assaults often violate the letter, if not the spirit, of human rights norms designed to protect civilians $[8, \mathrm{p} .4]$.

In the past 20 years, governments, rebels, politicians, diplomats, activists, demonstrators and journalists have referred to international humanitarian law and human rights in armed conflicts. International human rights law and international humanitarian law are now important parameters for many military commanders, advised on the ground by lawyers. Finally, they are often referred to by

\footnotetext{
"Abdiyeva Gunel Yashar - Researcher of "International Law" Department of the Institute on Law and Human Rights of Azerbaijan National Academy of Sciences. E-mail: abdiyevag@gmail.com
} 
defence lawyers and prosecutors in international and - to a still limited extent - domestic tribunals, and form the basis for well-reasoned verdicts [7, p.17].

Protection of human rights during armed conflicts is governed by international humanitarian law and international human rights law. While international human rights law and international humanitarian law have different historical and doctrinal roots, both share the aim of protecting all persons and are grounded in the principles of respect for the life, well-being and human dignity of the person.

International human rights law is a system of international norms designed to protect and promote the human rights of all persons. These rights, which are inherent in all human beings, whatever their nationality, place of residence, sex, national or ethnic origin, colour, religion, language, or any other status, are interrelated, interdependent and indivisible. They are often expressed and guaranteed by law, in the form of treaties, customary international law, general principles and soft law. Human rights entail both rights and obligations. International human rights law lays down the obligations of States to act in certain ways or to refrain from certain acts, in order to promote and protect the human rights and fundamental freedoms of individuals or groups [9, p.5].

International humanitarian law is a set of rules which seek, for humanitarian reasons, to limit the effects of armed conflict. It protects persons who are not or are no longer participating in the hostilities, and restricts the means and methods of warfare. Its scope is, therefore, limited to situations of armed conflict. International humanitarian law is part of jus in bello (the law on how force may be used), which has to be distinguished and separated from jus ad bellum (the law on the legitimacy of the use of force). The use of force is prohibited under the Charter of the United Nations. Nevertheless, international humanitarian law has to be applied equally by all sides to every armed conflict, regardless of whether their cause is justified. This equality between the belligerents also crucially distinguishes an armed conflict, to which international humanitarian law applies, from a crime, to which only criminal law and the rules of human rights law on law enforcement apply [9, p. 5].

The purpose of international humanitarian law is to limit the suffering caused by war by protecting and assisting its victims as far as possible. The law therefore addresses the reality of a conflict without considering the reasons for or legality of resorting to force. It regulates only those aspects of the conflict which are of humanitarian concern. It is what is known as jus in bello (law in war). Its provisions apply to the warring parties irrespective of the reasons for the conflict and whether or not the cause upheld by either party is just [14].

The jus ad bellum (law on the use of force) or jus contra bellum (law on the prevention of war) seeks to limit resort to force between States. Under the UN Charter, States must refrain from the threat or use of force against the territorial integrity or political independence of another state. Exceptions to this principle are provided in case of self-defence or following a decision adopted by the UN Security Council under chapter VII of the UN Charter [14].

Human Rights Law and International Humanitarian law. Both international human rights and humanitarian law are designed to protect the dignity and security of individuals by "guaranteeing and safeguarding human rights generally and in situations which require specific treatment" $[5, \mathrm{p}$. 356]. Nevertheless, there are some critical differences between the two that merit consideration. The first, and perhaps most significant, is the focus of these bodies of law. Humanitarian law is principally concerned with obligations of the state. Until the ratification of Additional Protocol II of the Geneva Conventions in 1977, law of war treaties addressed responsibilities of contracting parties 
(i.e., sovereign governments) toward the combatants and protected persons of other states and limitations on the methods of warfare. In this sense, humanitarian law is not different from other parts of international law in that the rights and responsibilities it delineates lie principally with sovereign states. In human rights law, however, the rights principally belong not to sovereign states, but to individuals. For the first time, people became not simply objects of international law through state obligations, but subjects of the law empowered to demand affirmative expectations of governments with regard to their own treatment. Second, humanitarian law is only applicable during periods of armed conflict and belligerent occupation. Human rights law, however, is applicable at least in all other circumstances besides armed conflict and, for certain actions (such as slavery and torture), during armed conflict as well. This expansive scope of human rights law has arguably affected the development of humanitarian law, advancing the notion that all people are "entitled to the enjoyment of human rights, whether in time of peace or war". Third principal difference is that whereas humanitarian law permits and even presumes harm done to individuals under certain circumstances, human rights law prohibits assaults on the dignity and security of individuals under virtually all circumstances [4].

When comparing norms of international human rights law and international humanitarian law, it becomes apparent that the latter protects only some human rights and only to the extent that they are particularly endangered by armed conflicts, and is not, as such, incompatible with the very existence of an armed conflict. Thus, the rights to social security, the right to free elections, freedom of thought or the right to self-determination are not covered by international humanitarian law [9, $\mathrm{p}$. 16].

As indicated above, international human rights law and international humanitarian law apply concurrently in situations of armed conflict, with their different protections complementing each other. However, there could be instances in which international human rights law and international humanitarian law regulate the same situation in a different manner, yielding different results. In such cases of conflict of norms, international practice has established that, failing other means to interpret both norms in conformity, one of the principles of interpretation of norms that could be applied is that of lex specialis. The lex specialis derogat legi generali principle reflects a widely accepted maxim of legal interpretation and technique for the resolution of normative conflicts. It establishes that, if a matter is being regulated by a general standard and at the same time by a more specific rule, then the latter should take precedence over the former. The relationship between the general standard and the specific rule may, however, be conceived in two ways. One is where the specific rule should be read and understood within the confines or against the background of the general standard, typically as an elaboration, update or technical specification of the latter. From a narrower perspective, lexs pecialis is also understood to cover the case where two legal provisions that are both valid and applicable are in no express hierarchical relationship and provide incompatible direction on how to deal with the same set of facts. In such a case, the application of the lex specialis principle is used to resolve conflicts of norms. In both cases, however, the rule with a more precisely delimited scope of application has priority [4].

The most visible problem in this arena is the killing or injury of civilians during armed conflict. In a strict legal sense this problem is governed by humanitarian law rather than human rights law. Nevertheless, it goes to the very heart of both of these legal regimes, which is protection of the dignity and security of the individual, in both peace and war [12, p. 35]. 
The most comprehensive legal framework for the protection of civilians during armed conflict to that point in history was contained in the Fourth Geneva Convention of 1949. Following a series of abuses in World War II such as the Allied firebombing of Tokyo and Dresden and the brutal Axis occupations of Poland and Manchuria, members of the international community decided that international norms regarding conduct in warfare needed to be strengthened and enhanced. The Fourth Geneva Convention lays out obligations of combatants vis-à-vis noncombatants in wartime, such as the prohibition of "(a) violence to life and person, in particular murder of all kinds, mutilation, cruel treatment and torture; b) taking of hostages; and c) outrages upon personal dignity, in particular, humiliating and degrading treatment." The brutality of wars of colonial liberation in the 1960s and 1970s suggested that the protections delineated in the Fourth Geneva Convention were not strong enough. As a result, some members of the international community negotiated and ratified the 1977 Additional Protocols I and II to the 1949 Geneva Conventions. Focusing on international and noninternational armed conflict respectively, the Additional Protocols delineated further protections for noncombatants in conflict [1].

Policy discussions regarding the scope of protection of civilians (POC) in peacekeeping missions continue to advance. Initially, the different missions provided their own interpretation of the concept and how it should be implemented based on their distinct operational environment, resources, and partners. For many, the concept hinged on physical protection, an area which peacekeeping missions have been uniquely placed to address among United Nations actors, but it was also understood by some to include the work to promote and protect human rights $[11, \mathrm{p} .6]$.

As a result of this lack of clarity, the Special Committee on Peacekeeping Operations (C34), representing those troop and police contributing countries which are often expected to implement much of the physical protection element of POC mandates and will thus be held accountable for delivering on it, to produce a concept of operations. This concept of operations delivered in 2011 went beyond physical protection to broaden the concept to include three main tiers or areas of work through which missions would contribute to the protection of civilians [3].

Tier 1: Protection through political process: Missions help to protect civilians through maintenance of peace during peace process or other political processes. The activities included in this tier include facilitation, mediation, support to reconciliation processes, and liaison between the negotiating parties.

Tier 2: Providing protection from physical violence: This tier includes the missions efforts to prevent, deter, and respond to situations in which civilians are under threat of physical violence. It includes patrolling, ensuring freedom of movement for humanitarians and the displaced, evacuation, public order management, conflict mediation, monitoring human rights, early warning, and political engagement. It is further sub-divided into four phases: assurance and prevention; pre-emption; response; and, consolidation.

Tier 3: Establishing a protective environment: This area of work encompasses promotion of legal protection; facilitation of humanitarian assistance and advocacy; and support to national institutions. More specifically in includes the wide range of mission activities ranging from human rights monitoring; child protection; prevention and response to sexual and gender-based violence; strengthening government capacity for the rule of law; disarmament, demobilization and reintegration; and security sector reform.

Practical approach of the European Court of Human Rights on application of the rules of international humanitarian law with the rules of European human rights law. 
In judgements delivered over the last few years, the European Court of Human Rights (ECHR or the Court) has ruled that the European Convention for the Protection of Human Rights and Fundamental Freedoms is applicable to the actions of the armed forces of States Parties engaged in military operations conducted outside their territory, which are also governed by international humanitarian law. This extension of the scope of application of the Convention has considerably increased the potential number of complaints that could be brought against Council of Europe member States, as evidenced by the recent cases brought before the Court against the Netherlands and the United Kingdom and also before national judges, the primary enforcers of the Convention. Yet while there is no question that the increasingly important place given to European human rights law in times of extraterritorial armed conflict extends the protections afforded to individuals, a too strict application of its rules could impose unrealistic obligations on States in this type of situation. In the long term, this could make them less inclined to comply with the law, and possibly with more basic rules of other branches of law, in particular with rules of international humanitarian law [13, p.1296].

In its judgement in the case of Hassan v. the United Kingdom of 16 September 2014, for the first time in its history, the Court has explicitly offered its view on the interaction between international humanitarian law and international human rights law and the operation of the Convention, particularly the right to liberty, in the context of an international armed conflict.

British forces arrested Tarek Hassan, an Iraqi national, who was found on the roof of the home of his brother (an Al-Quds General), armed with an AK-47 machine gun. Hassan was arrested and detained in a British-controlled section of the U.S. operated Camp Bucca in Iraq, on the grounds that he was a suspected combatant or a civilian posing a threat to security. Hassan was interrogated by both U.K. and U.S. authorities. Following a swift determination by both authorities that he was a non-combatant who did not pose a threat to security, he was released from Camp Bucca. His body, which displayed marks of torture and execution, was found months later many miles away from Camp Bucca, in an area not controlled by British forces [6].

The complaint under consideration by the ECHR was whether British authorities had failed to carry out an investigation into the circumstances of Hassan's detention, ill-treatment, and death, and whether Hassan's arrest and detention were arbitrary and unlawful, and lacking in procedural safeguards. The ECHR did not find any evidence to suggest either that Hassan had been ill-treated during his detention or that the British authorities were in any way responsible for his death. Accordingly, the United Kingdom had not been obliged to investigate the alleged ill-treatment (protected under Article 3 of the European Convention) nor had they failed to protect Hassan's right to life. The United Kingdom argued that Hassan did not fall under British jurisdiction because Camp Bucca was under U.S. control rather than under the effective control of British authorities. The Grand Chamber ruled that Hassan was under the authority and control, and thus the jurisdiction, of the United Kingdom from the moment of his arrest until his release [2].

The Grand Chamber has been consistent in its willingness to ascribe extraterritorial jurisdiction in situations involving overseas military operations. The most recent case in which the ECHR did so was Jaloud v. the Netherlands. In that case, Dutch forces had been manning a checkpoint in an area under British control in Iraq. Jaloud was shot and killed as his car passed through. The Grand Chamber found that "the Netherlands assumed responsibility for providing security in that area, to the exclusion of other participating States, and retained full command over its contingent there" and "exercised its jurisdiction" within the limits of its ... mission and for the purpose of as- 
serting authority and control over persons passing through the checkpoint" [10]. In both the Hassan and Jaloud cases, the Grand Chamber confirmed that authority and control of the relevant military conferred extraterritorial jurisdiction on the state parties sufficient to bring activities overseas under the scrutiny of the ECHR.

\section{CONCLUSION}

The problem with the protection of human rights in armed conflict is both complex and urgent. Millions of people suffer abuses because of warfare every year. Just as the problem is complex, so is the solution. There are at least three major elements should be considered for the protection of human rights in armed conflict.

First, treaties of international humanitarian law should be accepted and reaffirmedby all the states and communities of international law in order to make such norms universal. While the 1949 Geneva Conventions have been widely ratified and their provisions have achieved the force of customary international law, the same cannot be said for the provisions of the 1977 Additional Protocols, which contain even stricter standards for the protection of civilians.

Second, states must develop the tactical capacity that protects civilians as they engage the enemy. States should ensure that civilians in conflict zones can access medical care and humanitarian assistance, and they should enable humanitarian and health workers to work in safety.

Finally, the international community and the states must take more active steps to ensure security of civilians during and afterwards war.Governments can expend additional resources to ensure a secure environment in areas of conflict and thus protect civilians from abuses associated with lawlessness.

\section{References}

1. "Chapter V: Protection of Victims of Non-international Armed Conflicts: Extract from Basic Rules of the Geneva Conventions and their Additional Protocols," International Committee of the Red Cross, December 13, 1998. Available at: http://www.icrc.org/Web/eng/siteeng0.nsf/ iwpList104/6D73335C674B821DC1256B66005951D1 (accessed 10.02.2020).

2. Charlie Savage, U.S., Rebuffing U.N., Maintains Stance That Rights Treaty Does Not Apply Abroad, N.Y. TIMES, Mar. 13, 2014. Available at: http://mobile.nytimes.com/2014/03/14/world/us -affirms-stance-that-rights-treaty-doesnt-apply-abroad.html?_r=2\&referrer=; Human Rights Committee, Concluding Observations on the Fourth Periodic Report of the United States of America, U.N. Doc. CCPR/C/USA/CO/4 (accessed 10.02.2020).

3. Department of Peacekeeping Operations and Department of Field Support, "DPKO/DFS Op erational Concept on the Protection of Civilians in United Nations Peacekeeping Operations," 2011. Available at: https://www.stimson.org/wp-content/files/file-attachments/Considerations_for_a_ New_PKO_in_SSudanWorking_PaperStimsonMay2011_1.pdf (accessed 10.02.2020).

4. Fact Sheet No. 13, International Humanitarian Law and Human Rights," Office of the High Commissioner for Human Rights. Available at: http://www.unhcr.ch/html/menu6/2/ fs $13 . \mathrm{htm}$ (accessed 10.02.2020). 
5. Fragmentation of international law: difficulties arising from the diversification and expansion of international law - Report of the Study Group of the International Law Commission. Available at: https://undocs.org/pdf?symbol=ru/A/CN.4/L.682 (accessed 10.02.2020).

6. Hassan v. the United Kingdom, Judgment of Grand Chamber, Eur. Ct. H.R. (2014). Available at: http://hudoc.echr.coe.int/sites/eng/pages/search.aspx?1=001-146501 (accessed_02.03.2020).

7. Hector Gros Espiell, "Humanitarian Law and Human Rights Law" Januz Symonides (ed.) Human Rights: Concept and Standards. Burlington, VA: Ashgate Publishing Co., 2000.

8. Human rights in armed conflict from the perspective of the contemporary state practice in th e United Nations: Factual answers to certain hypothetical challenges, Ilia Siatitsa and Maia Titberidze. Available at: http://www.rulac.org/assets/downloads/State_practice_human_rights_ in_armed_conflict.pdf (accessed 10.02.2020).

9. International legal protection of human rights in armed conflict, United Nations, New York and Geneva, 2011. Available at: https://www.ohchr.org/Documents/Publications/HR_in_armed_ conflict.pdf (accessed 02.03.2020).

10. Jaloud v. The Netherlands, Judgment of Grand Chamber, Eur. Ct. H.R. (2014). Available at: http://hudoc.echr.coe.int/sites/eng/pages/search.aspx?i=001148367\#_Toc404269546 (accessed 02.03.2020).

11. Non-paper on protecting human rights in armed conflicts, UNICEF engagement with the protection of civilians agenda, 2014. Available at: http://www.unicefinemergencies.com/ downloads/eresource/docs/sanctions/Non-Paper\%20on\%20Protection\%20Human\%20Rights\%20in \%20Armed\%20Conflict.pdf (accessed 02.03.2020).

12. Paul Gordon Lauren, The Evolution of International Human Rights: Visions Seen - Second Edition. Philadelphia, PA: University of Pennsylvania Press, 2003.

13. Reconciling the rules of international humanitarian law with the rules of European human rights law, International Review of the Red Cross (2015), 97 (900).

14. https://www.icrc.org/en/doc/war-and-law/ihl-other-legal-regmies/jus-in-bello-jus-ad-bellum/ overview-jus-ad-bellum-jus-in-bello.htm (accessed 02.02.2020) 
Абдиева Г.Я.*

DOI: 10.25108/2304-1730-1749.iolr.2020.62.6-14

УДК 34:341

\section{Защита прав человека во время военных конфликтов}

Аннотация: Веками вооруженные конфликты уничтожали миллионы жизней. Во время вооруженных конфликтов наблюдаются серьезные нарушения закона. В некоторых случаях некоторые из этих нарушений даже происходят в форме геноцида и военных преступлений.

Международное право в области прав человека и международное гуманитарное право преследуют общую цель - сохранить достоинство и гуманность всех.

Дается правовой анализ международного права в области прав человека и международного гуманитарного права для защиты людей в вооруженных конфликтах. В нем также рассматривается дополнительное применение этих двух правовых норм и анализируется практический подход Европейского суда по правам человека к некоторым вопросам, возникающим в связи с одновременным применением международного гуманитарного права и европейского права в области прав человека.

Ключевые слова: вооруженные конфликты; права человека; международное право; гуманитарное право; государство; гражданское население; жертвы; оружие.

\section{Библиография}

1. «Глава V: Защита жертв вооруженных конфликтов немеждународного характера: выдержка из Основных правил Женевских конвенций и их дополнительных протоколов», Международный комитет Красного Креста, 13 декабря1998г. [Интернет ресурс]. Режим доступа: http://www.icrc.org/Web/eng/siteeng0.nsf/iwpList104/6D73335C674B821DC1256B660 05951D1 (дата обрашения: 02.10.2020).

2. Чарли Сэвидж. США, выступая против $\mathrm{OOH}$, придерживается позиции, что договор о правах не применяется за границей, Нью-Йорк Таймс, 13 марта 2014 г. [Интернет ресурс]. Режим доступа: http://mobile.nytimes.com/2014/03/14/world/us-affirms-stance-that-rights-treatydoesnt-apply-abroad.html?_r=2\&referrer=; Комитет по правам человека, Заключительные замечания по четвертому периодическому докладу Соединенных Штатов Америки, док. CCPR / C / USA / CO / 4 (дата обращения: 02.01.2020).

3. Департамент операций по поддержанию мира и Департамент полевой поддержки, «Оперативная концепция ДОПМ / ДФС по защите гражданских лиц в операциях Организации Объединенных Наций по поддержанию мира», 2011год. [Интернет ресурс]. Режим доступа: https://www.stimson.org/wp-content/files/file attachments/Considerations_for_ a_New_PKO_in_SSudanWorking_PaperStimsonMay2011_1.pdf (дата обращения: 10.02.2020).

\footnotetext{
- Абдиева Гюнель Яшар кызы - научный сотрудник отдела «Международное право» Института права и прав человека Национальной Академии Наук Азербайджана. E-mail: abdiyevag@gmail.com
} 
4. Информационный бюллетень № 13 «Международное гуманитарное право и права человека», Управление Верховного комиссара по правам человека. [Интернет ресурс]. Режим доступа: http://www.unhcr.ch/html/menu6/2/ fs13.htm (дата обращения: 10.02.2020).

5. Фрагментация международного права: трудности, возникающие в связи с диверсификацией и расширением международного права - доклад Исследовательской группы Комиссии международного права. [Интернет ресурс]. Режим доступа: https://undocs.org/pdf?symbol=ru/A/CN.4/L.682 (дата обращения: 10.02.2020)

6. Хасан против Соединенного Королевства, Решение Большой Палаты, Eur. Ct. H.R. (2014). [Интернет ресурс]. Режим доступа: http://hudoc.echr.coe.int/sites/eng/pages/search. aspx?1=001-146501(дата обращения: 02.03.2020).

7. Гектор Грос Эспиэль. «Гуманитарное право и право прав человека», Януз Симонидес (ред.) «Права человека: концепция и стандарты». Burlington, VA: Ashgate Publishing Co., 2000.

8. Права человека в вооруженном конфликте с точки зрения современной государственной практики в Организации Объединенных Наций: фактические ответы на некоторые гипотетические вызовы / Илья Сиатица и Майя Титберидзе. [Интернет ресурс]. Режим доступа: http://www.rulac.org/assets/downloads/State_practice_human_rights_in_armed_conflict. pdf (дата обращения: 10.02.2020).

9. Международно-правовая защита прав человека в вооруженных конфликтах, ООН, НьюЙорк и Женева, 2011 г. [Интернет ресурс]. Режим доступа: https://www.ohchr.org/Documents/ Publications/HR_in_armed_conflict.pdf (дата обращения: 02.03.2020).

10. Джалоуд против Нидерландов, решение Большой Палаты, Eur. Ct. H.R. (2014). [Интернет ресурс]. Режим доступа: http://hudoc.echr.coe.int/sites/eng/pages/search.aspx?i= 00114 8367\#_Тос404269546 (дата обрашения: 02.03.2020).

11. Неофициальный документ о защите прав человека в вооруженных конфликтах, участие ЮНИСЕФ в повестке дня защиты гражданских лиц, 2014 год. [Интернет ресурс]. Режим доступа: http://www.unicefinemergencies.com/downloads/eresource/docs/sanctions/NonPaper\% 20on\%20Protection\%20Human\%20Rights\%20in\%20Armed\%20Conflict.pdf (дата обращения: 02.03.2020).

12. Пол Гордон Лорен. Эволюция международных прав человека. Видение. Второе издание. - Филадельфия, Пенсильвания: Изд-во Пенсильванского университета, 2003.

13. Согласование норм международного гуманитарного права с нормами европейского права в области прав человека, Международный обзор Красного Креста (2015 год), 97 (900).

14.https://www.icrc.org/en/doc/war-and-law/ihl-other-legal-regmies/jus-in-bello-jus-ad-bellum/ overview-jus-ad-bellum-jus-in-bello.htm (дата обращения: 02.03.2020). 